by-product of low temperature carbonisation. It may be assumed that the gas will eventually be put to some better use than heating the setting, for otherwise the financial burden of the process would have to be carried entirely by the coke and the tar and light oilconditions which do not hold promise of smokeless fuel at a low price. As regards the economics of the process in general, though the report expresses no opinion, the data given as to plant and labour do not suggest low costs when compared with those of current carbonising practice.

The general impression which the report conveys is that the process yields a carbonised fuel rega ded as meeting domestic requirements which will probably prove costly per ton, and the scope of the process will depend on whether the general public will be prepared to pay the price for such smokeless fuel in order to avoid the atmospheric pollution following the use of raw coal.

H. J. H.

\section{Applied Science at the University of Brussels.}

THE highly successful celebrations in connexion with the fiftieth anniversary of the founding of the Applied Science School of the University of Brussels were held in the latter half of November, and were attended by the King of the Belgians, who received the foreign delegates, and also by the Duke of Brabant, who laid the foundation stone of a new building which will continue the development of the University. The city of Brussels and private donors have contributed largely to this scheme, as also the American Committee for the relief of Belgium. Great progress has been made in the buildings for pure and applied science at Solbosch, on the outskirts of Brussels, where, with ample space at disposal, it has been possible to erect a very fine block of buildings in the form of a hollow square.

Physics and chemistry are very well housed and equipped, and especial care has been taken to provide a number of small rooms for research work. The electrical engineering laboratories are remarkably well planned, and especially so as regards the arrangement of their numerous power circuits, which are carried round the walls below the windows and are protected by wire grillages. These circuits are connected to a number of panel units also completely enclosed and provided with the usual resistances, switch gear and measuring instruments all connected up in such a manner that students can readily trace out the various circuits, to which access is gained by numerous doors.

The main laboratory for investigating the strength and other physical properties of materials is chiefly notable for a fine equipment of Amsler testing machines housed in a spacious room provided with an overhead crane, and there are also a considerable number of accessory instruments for measurement and calibration work. A special photo-elastic laboratory is also arranged for in connexion with this department.

The laboratories for technical thermodynamics and hydraulics are now in course of equipment and are on a large scale typical of continental views of such matters, and, like the other laboratories, have welllighted basements with considerable head room, an arrangement which is especially convenient for steam plants and machinery dealing with the flow of liquids.

In connexion with the celebrations, a number of scientific and technical addresses were given, and numerous other functions were arranged by the Government, the University, and the civic authorities. E. G. C.

\section{University and Educational Intelligence.}

ABERDEEN.-The University Court has appointed Dr. A. Bowman to the lectureship on the scientific study of fisheries, in succession to Dr. T. Wemyss Fulton, resigned.

Prof. A. Findlay has proceeded on leave of absence to the United States, where he will act as substitute professor of chemistry at Leland Stanford University for the next nine months.

CAMBRIDGE.--The report of the Botanic Garden Syndicate refers to continued financial anxiety despite the generous support of Mr. Reginald Cory. A prospective legacy from an old friend of the Garden is referred to in the report at her special request in order that it may stimulate others to follow her excellent example. In the recent death of Mr. R. I. Lynch, Curator of the Garden from I879 until I9I9, a link with the past has been snapped. One item of interest in the report is the exchange of shrubs from the Garden for birds from the Zoological Society of London, two pairs of mandarin ducks having been recently received.

The John Bernard Seely Prize, formerly given for an essay in aeronautics, is in future to be awarded to the candidate who does best in aeronautics in the Mechanical Sciences Tripos.

Edinburgh.-Sir Richard Lodge, who has been Dean of the Faculty of Arts for thirteen years, has resigned this office, and the Faculty has elected Prof. E. T. Whittaker to succeed him as Dean. Prof. Hudson Beare and Prof. Lorrain Smith have been re-elected Deans of the Faculties of Science and Medicine respectively.

At its last meeting the University Court, on the recommendation of the Senatus, appointed Dr. Claude B. Ker, lecturer in infective fevers, to be a senior lecturer, with a seat on the Faculty of Medicine and on the Senatus, and Dr. E. M. Horsburgh, reader in technical mathematics, to be a member of the Senatus.

Dr. Douglas A. Allan, at present an assistant in the Department of Geology, has been appointed lecturer in geology in Armstrong College, University of Durham.

LoNDON.-The following doctorates have been awarded :-Ph.D. (Science), Mr. R. E. W. Maddison (King's College) for a thesis entitled "Part I. : The action of light on chlorine water and aqueous hypochlorous acid solutions; Part II.: Retardation and acceleration of certain chemical reactions by light of different wave-lengths "; Sachindranath Sen (Imperial College-Royal College of Science) for a thesis entitled "On the design of the Kew pattern barometer.'

We learn from the Chemiker Zeitung that Prof. A von Parseval has been nominated to the newly instituted chair of aviation at the Munich Technical Hochschule; and that Dr. Wilhelm Eitel, professor of physico-chemical mineralogy and petrography at Königsberg, has been invited to the chair of mineralogy
at Freiburg-im-Breisgau.

Applications are invited from medical graduates for the Marks lectureship in applied physiology and the Sheridan fellowship in the University of Adelaide. The applications, with testimonials, statement of academic qualifications, published researches, and a recent photograph, should be sent before the end of January, marked outside "Application for Marks Lectureship," to the Vice-Chancellor of the University, c/o the Agent-General for South Australia, Australia
House, Strand, W.C.2. 